\title{
Diversity of Phytoplankton in Iragbo Part of Yewa Lagoon, Southwest, Nigeria
}

\author{
Kokoette Sunday Effiong ${ }^{1, ~ *, ~ A n i e f i o k ~ I n i ~ I n y a n g ~}{ }^{2}$ \\ ${ }^{1}$ Department of Marine Sciences, Faculty of Sciences, University of Lagos, Akoka, Lagos, Nigeria \\ ${ }^{2}$ Department of Marine Biology, Faculty of Natural and Applied Sciences, Akwa Ibom State University, Ikot Akpaden, Nigeria
}

Email address:

kokoetteeffiong@gmail.com (K. S. Effiong), aniefiokinyang@yahoo.com (A. I. Inyang)

${ }^{*}$ Corresponding author

\section{To cite this article:}

Kokoette Sunday Effiong, Aniefiok Ini Inyang. Diversity of Phytoplankton in Iragbo Part of Yewa Lagoon, Southwest, Nigeria. American Journal of BioScience. Vol. 4, No. 4, 2016, pp. 41-48. doi: 10.11648/j.ajbio.20160404.11

Received: March 23, 2016; Accepted: April 5, 2016; Published: August 21, 2016

\begin{abstract}
A study of the diversity of phytoplankton in Iragbo part of Yewa Lagoon Lagos was conducted for six months, (December, 2012- May, 2013). The surface water transparency was $(\geq 48.5)$ and showed direct relationship with phytoplankton abundance. A total of 4875 individuals of 77 phytoplankton species belonging to 6 divisions were identified. Phytoplankton biomass was high in the dry months than wet months. Phytoplankton chlorophyll-a value (0.004) was highest in January. The Centrales diatoms dominated the phytoplankton community. A total of 1475 individuals (30.8\%) represents Bacillariophyta, while 635 (13.3\%), 15 (0.3\%), 2525 (52.8\%), $115(2.4 \%)$ and 20(0.4\%) represents Chlorophyta, Chrysophyta, Cyanophyta, Euglenophyta, and Pyrrophyta respectively. Cyanophyta were the most abundant $(52.8 \%)$ while Bacillariophyta had the highest species composition of 28 making up $(36.4 \%)$ of the total species. Diversity was higher in dry months $(\geq 3.42)$ than wet months ( $\leq 2.99$ ). Chlorophyll-a abundance showed positive correlation with Chemical Oxygen Demand (COD), Dissolved Oxygen (DO) and Iron (Fe).
\end{abstract}

Keywords: Chlorophyll-a, Diversity, Phytoplankton, Species-Evenness

\section{Introduction}

The lagoons of the tropical south-western Nigeria open into the Atlantic Ocean through the Lagos harbor all through the year [1]. Phytoplankton are free-floating microscopic plants that contain chlorophyll and grow by photosynthesis in the presence of sunlight, and lacks roots, stems and leaves [2, 3]. It is the power-house of the aquatic food web. The phytoplankton of an aquatic ecosystem is central to its normal functioning. While they constitute the starting point of energy transfer, they are highly sensitive to allochthonously imposed changes in the environment [4]. Nwankwo [5] while working on diatoms of Lagos lagoon observed that phytoplankton, like the terrestrial plants are seldom distributed completely at random due to variations in reproductive patterns, microhabitat preference or grazing.

There are quite a handful of records on the algal flora of south-western Nigeria. Adesalu and Nwankwo [6] reported a prominent role played by phytoplankton in Ogbe creek.
Nwankwo [7] observed seasonal changes of phytoplankton of Lagos Lagoon and adjacent sea in relation to environmental factors. Onyema [8] studied the epiphytic assemblage of a polluted estuarine creek in Lagos. Nwankwo et al. [9] observed the hydrochemistry and plankton dynamics of Kuramo Lagoon in Nigeria. Plankton studies in the Lagoon also include those of Olaniyan [10] who investigated the zooplankton, Inyang et al [11] who studied the composition of periphyton community on water hyacinth at Ejirin part of Epe Lagoon, Hendey [12] who studied the phytoplankton and Inyang et al [13] who did a comparative study of periphyton on Eichhornia crassipes and Phytoplankton communities at Ejirin part of Epe Lagoon, Sandison and Hill [14] described the distribution and effect of salinity on the life-cycle of Balamus in Lagos harbor and adjourning creeks.

Effiong and Inyang [1] carried out a study at Yewa Lagoon to evaluate the species composition of epiphyton algae on aquatic macrophyte and how it responds to the environmental changes, also to identify any indicator species of environmental importance in the epiphytic community. 


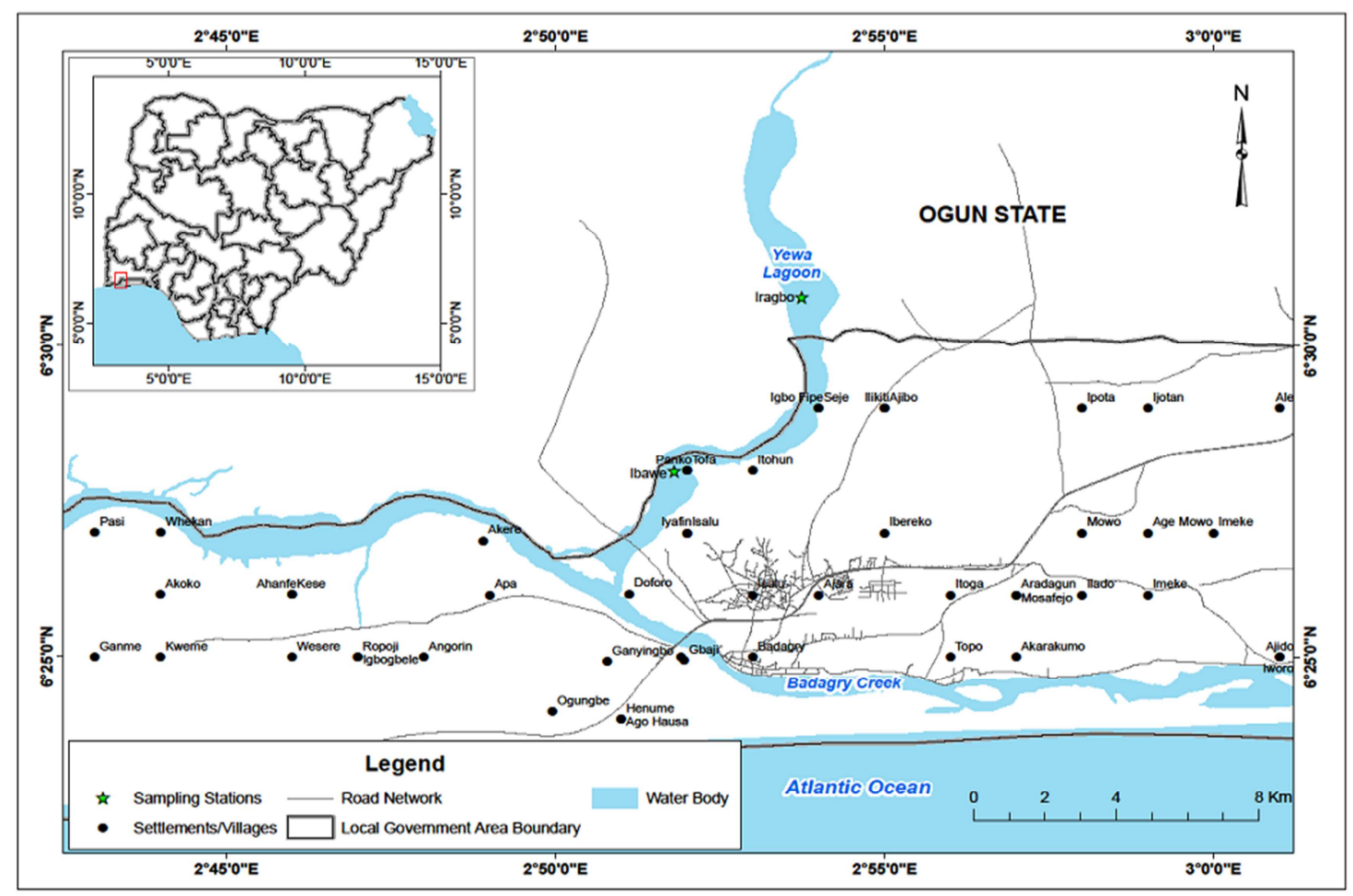

Fig. 1. Map of Yewa Lagoon showing sampling site.

The physiographic factors, rainfall and salinity determine the hydroclimate of the coastal Lagoons of south-western Nigeria $[14,10,5]$. The importance of rainfall in the ecology of south-western Nigeria has been documented [10, 15, 7]. Rainfall, for instance, initiates flood and dilute the ionic concentration of the coastal waters $[15,5,6]$, breaks down horizontal and vertical environmental gradients [15], limits transparency and phytoplankton production [16]. On the other hand, rainfall introduces chelating agents [7, 17], and increases nutrient brought in by river and surface water runoffs $[7,18]$.

In general, the temporal changes within a phytoplankton community itself are largely determined by the growth, mortality, sinking and migration or drifting rate of the individual plankton and other predators [19, 20,21].

The objective of this investigation was to study the composition and diversity of phytoplankton in Iragbo part of Yewa Lagoon.

\section{Materials and methods}

\subsection{Study Area}

The study site, Yewa Lagoon (Fig. 1) is one of the coastal Lagoons of South-Western Nigeria. It is located between Nigeria-Benin Republic boarder and Badagry lagoon. It lies approximately $6.21 \mathrm{~km}$ upstream of River Yewa, [22]. It experiences the characteristic seasonal rainfall that determines environmental gradients in South-Western Nigeria. River Yewa which is the major river emptying into the lagoon has Eere and Iragbo as tributaries, [1]. Mangrove vegetations such as the red mangrove (Rhyzophora $s p$ ) and black mangrove (Avvicenia $s p$ ) are abundant. Paspalum orbiculare, Acrostichum aureum, Phoenix rechinata and Nypa fructicans are some of the flora composition of Yewa lagoon. Manatees, migratory birds, periwinkle, aquatic crab, fishes of various species and snakes make up the fauna of Yewa lagoon. Economic activities such as artisanal fishing and sand mining are predominant.

\subsection{Collection of Samples}

Collection of water and plankton samples were carried out between 9:00hrs and 12:00hrs for six months (December, 2012- May, 2013)

Water samples were collected $20 \mathrm{~cm}$ below the surface water with $250 \mathrm{ml}$ screw-caped plastic bottles for physiochemical analysis. Chlorophyll-a sample, DO and BOD samples were collected in three $250 \mathrm{ml}$ amber bottles.

Plankton samples were collected using plankton net of $55 \mu \mathrm{m}$ mesh size towed for $5 \mathrm{mins}$ at low speed and preserved in $4 \%$ unbuffered formalin.

\subsection{Determination of Water Chemistry Parameters}

Phytoplankton samples were examined using Olympus model binocular microscope with calibrated eye piece using different magnification $(4 \mathrm{x}, 10 \mathrm{x}, 40 \mathrm{x}) .10$ drops of phytoplankton samples were investigated as described by Lackey, [23]. All organisms, unicels, filaments, coenobia were counted as one and recorded as per ml. Appropriate texts such as Hendey, [12], Patrick and Reiner, [24], Deskachey, [25] and Prescott, [26] were used for identification. 


\subsection{Chlorophyll-a Determination}

Chlorophyll-a was determined using method described by Holm-Harsen [27]. $250 \mathrm{ml}$ of water sample was filtered and the chlorophyll-a was extracted by methanol. The extraction was centrifuged at 320rpm for $10 \mathrm{mins}$ and absorbance was measured at different wave length, the chlorophyll-a concentration was measured using the formula below

$$
\text { Chlorophyll-a }(\mu \mathrm{g} / \mathrm{L})=\frac{(A b s[665 \mathrm{~nm}]-A b s[750 \mathrm{~nm}]) \times A \times V m}{V f \times L}
$$

Where; $\mathrm{A}=$ Absorbance coefficient of chlorophyll-a in methanol

$\mathrm{Vm}=$ Volume of methanol used for extraction

$\mathrm{Vf}=$ Volume of sample filtered

$\mathrm{L}=$ Path length of cuvette.

\subsection{Community Structure Analysis}

Community structure analysis were determined by four indices

Margelef index (d): This is a diversity of species richness, which does not take into account dominant diversity, but is largely dependent on the species richness, that is, the more the species present in a sample the greater the diversity [28].

$$
\mathrm{d}=\frac{S-1}{\log _{e} N}
$$

Where:

$\mathrm{d}=$ Diversity Index

$\mathrm{S}=$ Number of Species

$\mathrm{N}=$ Number of Individuals

$\log =$ Natural logarithm

$$
\mathrm{H}=\frac{N \log N-\sum f i \log f i}{N}
$$

Where:

$\mathrm{H}=$ Shannon-Wiener Information Index

$\sum=$ Summation

$\mathrm{fi}=$ Observed proportion of individuals that belong to the ith species

$\log _{\mathrm{e}}=$ Natural logarithm.

\subsection{Species Equitability or Evenness (j) Jaccard.}

This is a measure of how evenly the individuals are distributed among the species present in a sample. It ranges between 0 and 1, the maximum value. One represents a situation where individuals are spread evenly among the species present [29].

It was calculated as follows:

$$
\mathrm{j}=\frac{H}{H_{\max }} \text { or } \mathrm{j}=\frac{H}{\log S}
$$

Where:

$\mathrm{j}=$ Equitability measure

$\mathrm{H}=$ Shannon-Wiener Information Index

$\mathrm{S}=$ Number of species in the sample.

\subsection{Similarity Index (Nwankwo)}

The Similarity Index (S) between two samples is given by the equation:

$$
\mathrm{S}=\frac{2 C}{A+B}
$$

Where:

$\mathrm{S}=$ Similarity index

$\mathrm{C}=$ Number of species common to both samples

$A=$ Number of species in sample $A$

$B=$ Number of species in sample $B,[30]$

\section{Results}

\subsection{Hydro Climate Properties}

Data on some hydroclimatic features of the sample site at Yewa Lagoon is presented in table 1. The highest surface water temperature $\left(32.2^{\circ} \mathrm{C}\right)$ was recorded in February while the lowest $\left(30.2^{\circ} \mathrm{C}\right)$ was recorded in December. Similarly, higher $\mathrm{pH}$, conductivity, DO and transparency values were recorded in the dry months than in the wet months (Table 1). On the other hand, Total Dissolved Solids (TSS), nutrients

\begin{tabular}{|c|c|c|c|c|c|c|}
\hline \multirow[b]{2}{*}{ PARAMETERS } & \multicolumn{6}{|c|}{ MONTHS } \\
\hline & DEC. & JAN. & FEB. & MAR. & APR. & MAY \\
\hline $\begin{array}{l}\text { Surface water } \\
\text { temperature }\left({ }^{\circ} \mathrm{C}\right)\end{array}$ & 30.2 & 30.8 & 32.2 & 31.8 & 31.3 & 30.5 \\
\hline Transparency $(\mathrm{cm})$ & 37.5 & 48.5 & 35.0 & 34.0 & 30.3 & 28.0 \\
\hline $\begin{array}{l}\text { Total Suspended } \\
\text { Solids (mg/L) }\end{array}$ & 49.0 & 46.0 & 37.0 & 45.0 & 56.0 & 68.0 \\
\hline Rainfall (mm) & 13.2 & 0.0 & 28.0 & 50.1 & 165.3 & 340.8 \\
\hline Conductivity $(\mu \mathrm{s} / \mathrm{cm})$ & 94.0 & 97.0 & 99.0 & 83.0 & 80.0 & 78.0 \\
\hline $\mathrm{pH}$ & 8.0 & 7.6 & 8.2 & 7.5 & 7.3 & 7.0 \\
\hline $\begin{array}{l}\text { Dissolved Oxygen } \\
(\mathrm{mg} / \mathrm{L})\end{array}$ & 4.5 & 7.6 & 7.1 & 5.1 & 3.6 & 2.8 \\
\hline $\begin{array}{l}\text { Biochemical Oxygen } \\
\text { Demand }(\mathrm{mg} / \mathrm{L})\end{array}$ & 9.0 & 10.0 & 10.0 & 13.0 & 16.0 & 16.0 \\
\hline $\begin{array}{l}\text { Reactive Phosphate } \\
(\mathrm{mg} / \mathrm{L})\end{array}$ & 0.5 & 0.8 & 0.5 & 6.8 & 6.9 & 10.1 \\
\hline $\begin{array}{l}\text { Reactive Nitrate } \\
(\mathrm{mg} / \mathrm{L})\end{array}$ & 0.1 & 0.2 & 3.1 & 16.8 & 18.1 & 33.0 \\
\hline Sulphate (mg/L) & 0.01 & 0.02 & ND & 7.0 & 8.0 & 7.9 \\
\hline Iron $(\mathrm{mg} / \mathrm{L})$ & 0.072 & 0.07 & 0.07 & 0.34 & 0.208 & 0.068 \\
\hline Silicate $(\mathrm{mg} / \mathrm{L})$ & 0.003 & 0.004 & ND & 0.003 & 0.002 & 0.003 \\
\hline Chlorophyll a & 0.003 & 0.004 & 0.002 & 0.001 & 0.001 & 0.001 \\
\hline $\begin{array}{l}\text { Phytoplankton } \\
\text { density (cell/ml) }\end{array}$ & 525 & 2450 & 630 & 440 & 460 & 415 \\
\hline
\end{tabular}
and Biochemical Oxygen Demand (BOD) values were higher in the wet months than during the dry months.

Table 1. Variations in some physical and chemical parameters in Iragbo part of Yewa Lagoon (December, 2012-May 2013).

$\mathrm{ND}=$ Not Detected

Higher sicche disc readings in the dry months coincided with periods of drop in TSS values. Phosphates-phosphorus recorded a progressive increase into the wet months $(\geq 0.5$; $\leq$ $10.1)$ and nitrate level increases steadily and were very high 
during the wet months. Silicate values rose steadily in December and January, but fluctuated slightly in other months.

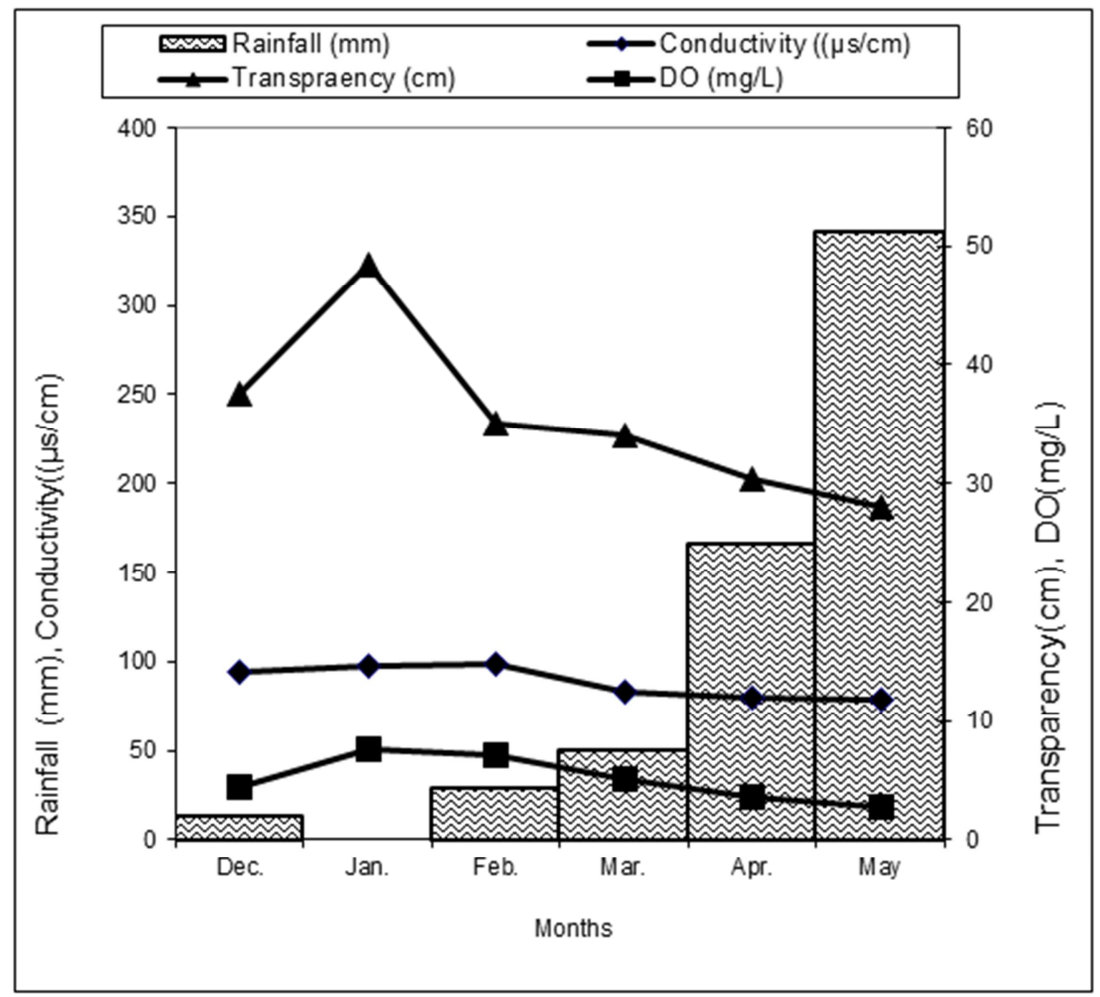

Fig. 2. Monthly variation in Rainfall, Transparency, DO and Conductivity in Iragbo part of Yewa Lagoon (December, 2012- May, 2013).

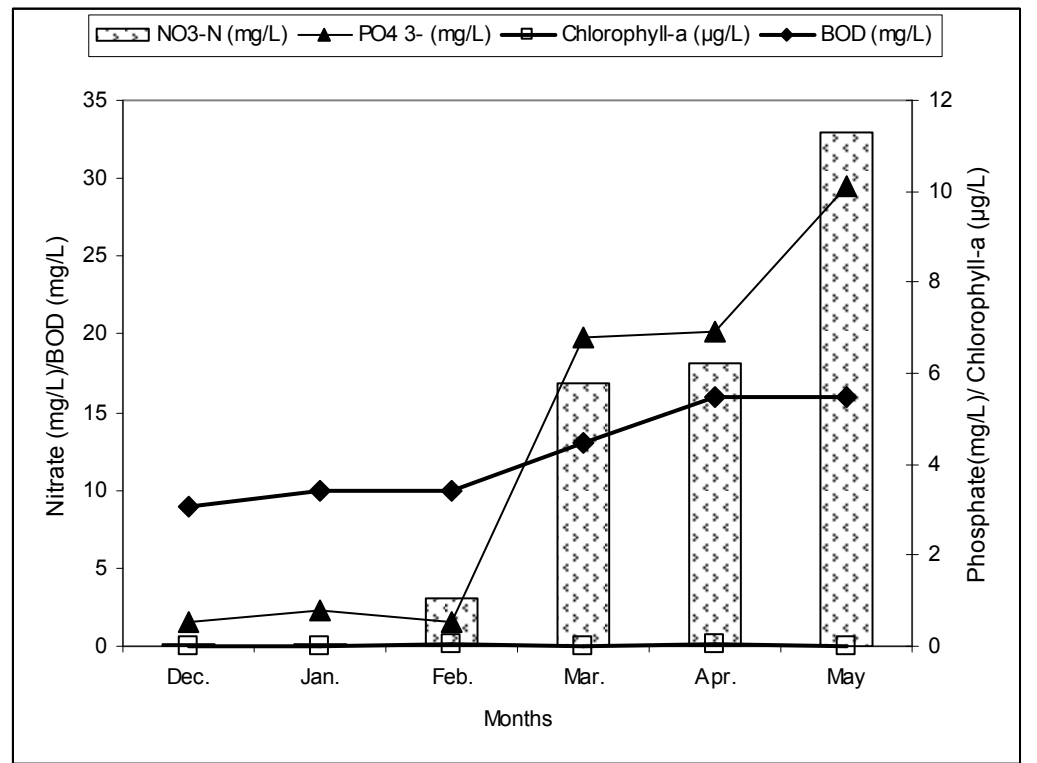

Fig. 3. Monthly variation in Nitrate, Phosphate, BOD and Chlorophyll-a in Irabgo part of Yewa Lagoon (December, 2012-2013).

\subsection{Diatom Community}

The diatom population during the study was dominated by 15 centric diatoms while the pennales were 13. The Aulocoseira and Coscinodiscus species dominated the centric diatom. However, species of Oscillatoria tenius and Microcystis aeroginosa (blue green algae) contributed the largest number of individuals $(38.7 \% ; 11.6 \%)$ of total cell numbers throughout the study period. Other genera with high number of individuals were Aulacoseira granulata (8.3\%), A. granulata var. angustissima f. spiralis (5.9\%). The phytoplankton in the Iragbo part of Yewa Lagoon belonged to six main divisions (abundance): Bacillariophyta 1475(30.8\%), Chlorophyta 635(13.3\%), Cyanophyta 2525(52.8\%), Euglenophyta 115(2.4\%), Crysophyta 15(0.3\%) and Pyrophyta 20(0.4\%). Phytoplankton in Yewa 
Lagoon in terms of species composition are as follows; Bacillariophyta 28(36.4\%), Chlorophyta 23(29.8\%), Chrysophyta $8(10.4 \%)$, Cyanophyta 11(14.3\%), Euglenophyta 3(3.9\%) and Pyrophyta 4(5.2\%). A total of 77 species belonging to 35 genera were identified. Throughout the sampling period, the highest (2450 individuals per $\mathrm{ml}$ ) (53\%) phytoplankton occurrence was recorded in January, while the least (415 individuals per $\mathrm{ml}$ ) $(9 \%)$ was recorded in May. Thirteen phytoplankton orders were also recorded throughout the sampling months, namely; Centrales, Pennales, Chlorococcales, Volvocales, Zygnemata les, Hormogonales, Euglenales, Mischoculales, Dinokontae, Gonyaulacales and Nocticulales.

Table 2. Species list and percentage composition of phytoplanktonic algae colonizing Iragbo part of Yewa Lagoon.

\begin{tabular}{|c|c|}
\hline PHYTOPLANKTONTAXA & $\%$ OCCURRENCE \\
\hline Diatoms & 30.8 \\
\hline \multicolumn{2}{|l|}{ Division: BA CILLARIOPHYTA } \\
\hline \multicolumn{2}{|l|}{ Class: BACILLARIOPHYCEAE } \\
\hline \multicolumn{2}{|l|}{ Order I: CENTRALES } \\
\hline \multicolumn{2}{|l|}{ Family: COSCINODISCACEAE } \\
\hline Aulacoseira granulata Ehrenberg & 8.3 \\
\hline A. granulata var. angustissima (Ehr.) Ralfs & 4.4 \\
\hline A. granulata var. angustissima f. spiralis Muller & 5.9 \\
\hline A. italica var. subarctica $\mathrm{O}$. Muller & 0.1 \\
\hline Bacteriosira fragilis & 1.4 \\
\hline Coscinodiscus concinnus & 0.2 \\
\hline Coscinodiscus lineatus Ehrenberg & 0.1 \\
\hline Coscinodiscus marginatus Ehrenberg & 0.2 \\
\hline Coscinodiscus nitidus & 0.7 \\
\hline Cyclotella comta Kützing & 0.8 \\
\hline C. stelligera Cleve and Grunow & 0.4 \\
\hline Melosira islandica & 0.3 \\
\hline Stephanodiscus astraea Grunow & 0.1 \\
\hline \multicolumn{2}{|l|}{ Family: LEPTOCYLINDRACEAE } \\
\hline Leptocylindrus daniscus & 2.9 \\
\hline \multicolumn{2}{|l|}{ Family: RHIZOSOLENIACEAE } \\
\hline Rhizosolenia stolterfothii & 0.1 \\
\hline \multicolumn{2}{|l|}{ Order II: PENNALES } \\
\hline \multicolumn{2}{|l|}{ Family: FRAGILARIACEAE } \\
\hline Diatoma vulgaris & 0.1 \\
\hline Synedra acus & 0.3 \\
\hline Synedra ulna (Nitzsch) Ehrenberg & 0.1 \\
\hline Tabellaria flocculosa (Roth) Kutzing & 0.1 \\
\hline Thalassiothrix nitzschioides Grun. & 1.3 \\
\hline T. spattulata & 0.6 \\
\hline \multicolumn{2}{|l|}{ Family: GOMPHONEMACEAE } \\
\hline Gomphonema parvulum var. lagenula & 0.1 \\
\hline \multicolumn{2}{|l|}{ Family: ACHNANTHACEAE } \\
\hline Cocconeis placentula & 0.2 \\
\hline \multicolumn{2}{|l|}{ Family: NAVICULACEAE } \\
\hline Navicula elliptica & 0.1 \\
\hline Pinnularia major & 0.1 \\
\hline Stauroneis phoenicentron $\mathrm{f}$. gracilis & 0.1 \\
\hline \multicolumn{2}{|l|}{ Family: NITZSCHIACEAE } \\
\hline Nitzschia longissima & 1.9 \\
\hline Nitzschia tryblionella var. victoriae & 0.1 \\
\hline Green Algae & 13.3 \\
\hline \multicolumn{2}{|l|}{ Division: CHLOROPHYTA } \\
\hline \multicolumn{2}{|l|}{ Class: CHLOROPHYCEAE } \\
\hline \multicolumn{2}{|l|}{ Order I: CHLOROCOCCALES } \\
\hline \multicolumn{2}{|l|}{ Family: CHLOROCOCCACEAE } \\
\hline Chlorella sp. Butcher & 2.1 \\
\hline Chlorella vulgaris Butcher & 3.3 \\
\hline
\end{tabular}

\begin{tabular}{|c|c|}
\hline PHYTOPLANKTONTAXA & \% OCCURRENCE \\
\hline Oocystis lacustris & 0.1 \\
\hline Palmellococcus minutus Kutz. & 0.5 \\
\hline Tetraëdron regulare var.incus & 0.2 \\
\hline \multicolumn{2}{|l|}{ Family: HYDRODICTYACEAE } \\
\hline Hydrodictyon reticulatum & 1.0 \\
\hline Pediastrum biradiatum Meyen & 0.1 \\
\hline P. clathratum (A. Brawn) Lengerth & 0.7 \\
\hline P. duplex & 0.4 \\
\hline \multicolumn{2}{|l|}{ Family: SCENEDESMACEAE } \\
\hline Actinastrum hantzchii & 0.6 \\
\hline A. hantzchii var. fluviatile & 0.7 \\
\hline Crucigena minima & 0.1 \\
\hline Tetrastrum sp. & 0.2 \\
\hline \multicolumn{2}{|l|}{ Order II: VOLVOCALES } \\
\hline \multicolumn{2}{|l|}{ Family: VOLVOCACEAE } \\
\hline Pandorina morum & 0.1 \\
\hline Volvox globator & 0.1 \\
\hline \multicolumn{2}{|l|}{ Order III: ZYGNEMATALES } \\
\hline \multicolumn{2}{|l|}{ Family: DESMIDIACEAE } \\
\hline Closterium acutum & 0.1 \\
\hline C. arcuarium & 0.1 \\
\hline C. cornu var. javanicum & 0.6 \\
\hline Hyalotheca dissiliens & 0.1 \\
\hline \multicolumn{2}{|l|}{ Order IV: Ulotrichales } \\
\hline \multicolumn{2}{|l|}{ Family: Ulotrichaceae } \\
\hline Stichococcus bacillaris & 1.5 \\
\hline \multicolumn{2}{|l|}{ Family: MESOTAENIACEAE } \\
\hline Golenkinia radiata Chodat & 0.4 \\
\hline Gonatozygon kinahanii & 0.1 \\
\hline \multicolumn{2}{|l|}{ Family: ZYGNEMATACEAE } \\
\hline Spirogyra africana Fritsch Cruda & 0.1 \\
\hline Blue green algae & 52.8 \\
\hline \multicolumn{2}{|l|}{ Division: CYANOPHYTA } \\
\hline \multicolumn{2}{|l|}{ Order I: CHROOCOCCALES } \\
\hline \multicolumn{2}{|l|}{ Family: CHROOCOCCACEAE } \\
\hline Chroococcus disperses & 0.2 \\
\hline Chroococcus pallidus Nageli & 0.1 \\
\hline Microcystis aeruginosa f. flos-aquae & 0.1 \\
\hline Microcystis aeruginosa Kutzing & 11.6 \\
\hline \multicolumn{2}{|l|}{ Order: HORMOGONALES } \\
\hline \multicolumn{2}{|l|}{ Family: NOSTOCACEAE } \\
\hline $\begin{array}{l}\text { Anabaena spiroides Klebahn var. minima } \\
\text { Nygaard }\end{array}$ & 1.0 \\
\hline A. spiroides Klebahn var. tumida Nygaard & 1.1 \\
\hline Family: OSCILLATORIACEAE & \\
\hline Oscillatoria $s p$ & 38.7 \\
\hline Oscillatoria tenius Agardh & 0.1 \\
\hline Euglenoids & 2.4 \\
\hline Division: EUGLENOPHYTA & \\
\hline Order: EUGLENALES & \\
\hline Family: EUGLENACEAE & \\
\hline Euglena ehrenberghii & 0.6 \\
\hline Phacus caudatus & 0.1 \\
\hline P. longicauda & 0.1 \\
\hline P. longicauda var. rotundus & 0.6 \\
\hline P. oblonga var. planctonica & 0.1 \\
\hline Phacus sp. & 0.1 \\
\hline Trachelomonas conica & 0.2 \\
\hline T. nigerica & 0.1 \\
\hline T. robusta & 0.1 \\
\hline T.volvocina & 0.1 \\
\hline T. volvocinopsis var. punctata & 0.2 \\
\hline Silicoflagellates & 0.3 \\
\hline Division: CHRYSOPHYTA & \\
\hline Order: MISCHOCCOCALES & \\
\hline Family: SCIADACEAE & \\
\hline Centritractus belonophorus & 0.1 \\
\hline
\end{tabular}




\begin{tabular}{ll}
\hline PHYTOPLANKTONTAXA & \% OCCURRENCE \\
\hline Ophiocytium capitatum Wolle & 0.1 \\
Tetrasporopsis perforate & 0.1 \\
Dinoflagellates & 0.4 \\
Division: PYRRHOPHYTA & \\
Class: DINOPHYCEAE & \\
Order: DINOKONTAE & \\
Family: PERIDINIACEAE & \\
Peridinium cinctum & 0.1 \\
Family: GYMNODINIACEAE & \\
Gymnodinium excavatum & 0.1 \\
Order: GONYAULACALES & \\
Family: GONIODOMATACEAE & \\
Alexandrium catenella & \\
Order: NOCTILUCALES & 0.1 \\
Family: NOCTILUCACEAE & \\
Noctiluca scintillans & \\
\hline
\end{tabular}

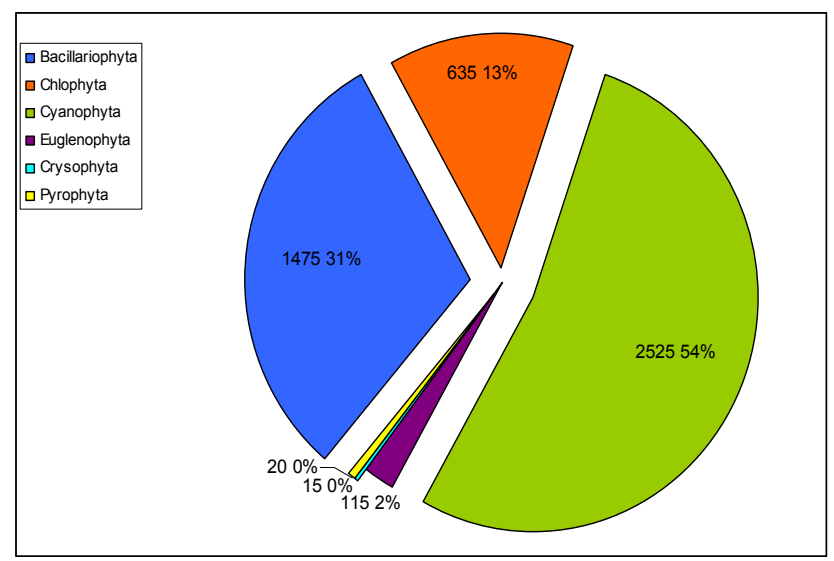

Fig. 4. Relative abundance of phytoplankton divisions that occurred in Iragbo part of Yewa Lagoon from December, 21012-May, 2013.

\subsection{Community Structure}

Table 3. Variations in species richness (d) and Shannon \& Weaver index (H) across months in Iragbo part of Yewa Lagoon.

\begin{tabular}{lllllll}
\hline \multicolumn{7}{l}{ MONTHS } \\
\hline INDICES & DEC. & JAN. & FEB. & MAR. & APR. & MAY \\
Species Richness (d) & 5.91 & 3.72 & 3.41 & 3.45 & 3.09 & 2.99 \\
Shannon and Weaver (H) & 1.95 & 1.43 & 1.42 & 1.18 & 1.10 & 1.09 \\
\hline
\end{tabular}

\subsection{Species Diversity}

All through the sampling period, both species richness (d) and Shannon \& Weaver index $(\mathrm{H})$ decreased as wet months approached. Generally, diversity was low between April and May, a pattern possibly related to low light penetration caused by high turbidity.

\section{Discussion}

The present information on the hydrology and water chemistry of the Yewa Lagoon confirms earlier observations that quantity of rainfall and distributive pattern determines the annual lagoonal environment $[15,31,7,17]$. For instance, turbidity which decreases light penetration thereby reducing photosynthesis is directly linked with the rainfall pattern.
According to PUDO [32] physical and chemical factors in the Nigerian coastal waters create serious environmental limitations and have influence on organism development and biocenosis formation.

The physical and chemical changes observed in the Lagoon may have been as a result of hydroclimatic changes linked to the seasons. For instance, the dry months concentrated between December and March was accompanied by higher conductivity, higher temperature and higher transparency. On the other hand, changes may be linked to impacts of leacheates into the Lagoon from Yewa River, associated creeks and wetlands in the wet months. Similar observations were made by Nwankwo [18, 33] in Lagos Lagoon. Dissolved oxygen and $\mathrm{pH}$ were the major factors in water quality affected by pollutants. In most cases, depletion of oxygen is as a result of bacterial degradation of the organic constituents utilizing oxygen. The increase DO values in the mid dry months could be due to the rule played by aquatic vegetation in increasing the oxygen levels in water. Barcleys [34] in a temporary pond near Auckland, New Zealand, observed an increase in DO at wet season. Conductivity was relatively stable all through the months possibly due to lack of intrusion of sea water. Interestingly, the natural $\mathrm{pH}$ of fresh water like the Yewa Lagoon is well known to be more acidic but in this work, it is seen to be more alkaline possibly as a result of leachates from Ewekoro cement Company.

Lagoons of south-western Nigeria are known to be of two types, some like the Iyagbe and Lagos lagoons directly influenced by tidal sea are said to be physically influenced while others like Yewa, Lekki, Kuramo, Badagry, Mahin, Ologe and Epe lagoons are said to be biologically controlled, [35]. The rising values of micro nutrients between March and May could be due to increase in inflow from rivers and creeks as a result of exudates carried by the flooding water. Reactive silicate values was less in months where there is high diatom biomass, this may be due to the fact that diatoms use reactive silicate to build its frustules. The abundance of phytoplankton algae population during dry months maybe due to stability of the Lagoon water, higher light penetration enhanced by higher transparency, higher photosynthetic depth, lower TSS and TDS. Nwankwo and Onitiri [36] on periphyton community on submerged aquatic macropohytes in Epe Lagoon made similar observations. On the other hand, the paucity of diatom taxa during the short wet months of the study may be due partly to poor penetration of light into the moderately colored water, low dissolved oxygen values, increasing levels of BOD and COD. Patrick, [37] suggested that the number of diatom genera in an aquatic environment is reduced by pollution. Chlorophyll-a abundance showed positive correlation with COD, DO and Iron though not significant. The rising values of Iron between March and April showed a slight increase in plankton biomass, this may confirm the fact that algae especially diatoms require Iron for growth.

The varying species composition observed maybe due to the varying levels and other environmental factors. WEBB [38] pointed out that rainfall in the tropics is more important than temperature in determining environments. It is therefore 
possible that the knowledge of rainfall pattern in and around the Lagoon would help determine the floristic communities at any time. According to KARENTE AND MCINTIRE [39] the number of species in an assemblage and the degree of evenness are closely related to the species diversity. Low values of the diversity index indicate dominance by one or two species and higher values indicates that the species numbers are more evenly dispersed. This probably explains the low evenness (j) values between January and March when Aulacoseira granulata, A. granulata var. angustissima and $A$. granulata var. angustissima $f$. spiralis were predominant in the plankton hauls. Nwankwo, [33] working on phytoplankton diversity and succession in Lagos Lagoon also made similar observations.

Phytoplankton is the base of aquatic food web which affects the food production [40]. Diatoms have been used by ecologist to indicate pollution in water bodies and other variations of ecological conditions. Species diversity index also could be used to determine the growth rate, occurrence, distribution and of course the species composition of the phytoplankton community. Phytoplankton algal species that could be used as indicators of organic pollution identified include: DiatomsGomphonema parvulum, Synedra acus, Pinnularia major. Green algae- Chlorella vulgaris, Actinastrum hantzschii. Euglenoids- Phacus longicuda. This shows that the Iragbo part of Yewa Lagoon maybe organically polluted. The majority of algal species identified in this work has already been identified by other authors working in the several Lagoons found in south-western Nigeria.

\section{Conclusion}

Phytoplankton biomass was higher in the dry months due to relative stability of the lagoon water and higher light penetration, this implies that during wet months the lagoon receives substantial amount of inland waters through its many tributary, resulting to low light penetration, high turbidity and high TSS thereby resulting to paucity of diatoms in wet months.in all the sampling period, both species richness (d) and Shannon and Weaver index $(\mathrm{H})$ decreased as wet months approached. A total of 4875 individual of 77 phytoplankton species belonging to 6 divisions were identified. The centrales diatoms dominated the phytoplankton species; diatoms have been used by ecologists to indicate pollution status of water bodies and other variations of ecological conditions. Phytoplankton species that could be used as indicators of organic pollution identified in this study include: DiatomsGomphonema parvulum, Synedra acus, Pinnularia major; Green algae-Chlorella vulgaris, Actinastrum hantzchii; Euglenoids-Phacus longicuda, the lagoon may be gradually organically polluted.

\section{Acknowledgement}

The authors are grateful to the staff of Marine Biology Laboratory, University of Lagos for field assistance and sample analysis. Special thanks go Prof. Nwankwo, D. I. for his expertise advice and meticulous assessment of the work.

\section{References}

[1] Effiong, K. S. and Inyang, A. I. (2015). Epiphytic Algae on Aquatic Macrophyte (Water Hyacinth) in a Tropical Lagoon and their Possible Use as Bioindicator. International Journal of Environmental Monitoringand Analysis 2015; 3(6): 404-410.

[2] Lee, R. E. (1999). Phycology. Cambridge University Press, New York. 614pp.

[3] Nwankwo, D. I. (2004). Studies in the environmental preference of blue-green algae (Cyanophyta) in Nigerian coastal waters. Journal of Nigeria Environmental Society. 2(1): 44-55.

[4] Khattak, T. M, Noorzaman Bhatti, Ghulam Murtaza. (2005). Evaluation of Algae from the Effluent of Dandot Cement Company, Dandot, Pakistan. J. Appl. Sci. Environ. Mgt. 9(1) 147-149.

[5] Nwankwo, D. I. (1990). Contribution to the Diatom flora of Nigeria. Diatoms of Lagos Lagoon and the adjacent sea. Nigerian Journal of Botany. 3:53-70.

[6] Adesalu, T. A and Nwankwo, D.I. (2005). Studies on the phytoplankton of Olero Creek and parts of Benin River, Nigeria. The Ecologia. 3(2): 21-30.

[7] Nwankwo, D. I. (1984). Seasonal changes of phytoplankton of Lagos and adjacent sea in relation to environmental facors, Ph.D. Thesis. University of Lagos. 447pp.

[8] Onyema, I.C. and Nwankwo, D. I. (2006). The epiphytic assemblages of a polluted estuarine creek in Lagos. Nig. Pol. Res. 25: 459-468.

[9] Nwankwo, D. I., Owoseni, T. I., Usilo, D. I., Obiyan, A. C. and Onyema, I.C. (2008). Hydrochemistry and plankton dynamics of Kuramo Lagoon. Life Science Journal. 5(1): 83-88.

[10] Olaniyan, C. I. O. (1957). The seasonal variation in plankton in Lagos Harbour, Nigeria. -Ph.D. Thesis, University of London, 173pp.

[11] Inyang AI, Sunday KE, Nwankwo, DI. (2015). Composition of Periphyton Community on Water Hyacinth (Eichhornia crassipes): In Analysis of Environmental Characteristics at Ejirin Part of Epe Lagoon in Southwestern Nigeria. Journal of Marine Biology. 2015; 1-9.

[12] Hendey, N. I (1964). An introductory account of the small algae of the British coastal water. Port V. Bacillariophyceae. (Diatom) Ministry of Agriculture, Fisheries and food London Fisheries investigation series. 4:317pp.

[13] AI Inyang, KS Effiong and MU Dan (2015). A Comparative Study of the Periphyton on Eichhornia crassipes and Phytoplankton Communities: An Overview of Environmental Conditions at Ejirin Part of Epe Lagoon, South Western Nigeria. British Journal of Applied Science \& Technology. 10(5): 1-23pp.

[14] Sandison, E. E. and Hill, M. B. (1966). The distribution of Balanus pallidus strusburi Darwin, Cryphaea gasar (Adanson) Dantzenberg, Mercicerella enigmatica Farvel and Hydroides uniciata (philip) in relation to salinity in Lagos Harbour and adjacent creek. J. Anim.Ecol., 38: 235-258. 
[15] Hill, M. B. and Webb, J. E. (1958). The Ecology of the Lagos Lagoon II. The topography and physical features of Lagos harbour and Lagos Lagoon. Physiological transactions of the Royal Society London. 421-447.

[16] Nwankwo, D. I. (1991). Phytoplankton algae on fish fences 'acadja' in a tropical open lagoon. International Journal of Ecology and Environmental Sciences. 17: 1-10.

[17] Nwankwo, D. I. and Akinsoji, A. (1992). Epiphytic community on water hyacinth Eichhornia crassipes (Mart) Solms. In coastal waters on south-western Nigeria. Archive Hydrobiologie. 124 (4): 501-511.

[18] Nwankwo, D. I. (1993). Cyanobacteria bloom species in coastal waters South-West Nigeria. Archive fur hydrobiology. 90: 543-553.

[19] Mann, K.A (2000). Ecology of Coastal waters with implication for management $\left(2^{\text {nd }}\right.$ edition). Blackwell Science Incorporated, Massachusetts. 406pp.

[20] Prasaad, S. N. (2000). Marine Biology. Campus Book International, New Delhi. 467pp.

[21] Marder, S.S. (2001). Biology. In: Diversity of the protists. Kane, K. T., Reiddy, P. E Melde, A and Love, D. (Eds.). $7^{\text {th }}$ edition. The MacGraw-Hill Componies, Inc., New York. 528540pp.

[22] Egborge ABN. Water hyacinth - biological museum. Proceedings of the International Workshop on Water Hyacinth, Lagos. 1988; 52-70.

[23] Lackey, J.B. (1938). The Manipulation and counting of river plankton and changes in some organisms due to formalin preservation. US Public Health Reports. 63: 2080-2093.

[24] Patrick, R. and Riener, C. W. (1975). The diatom of the United State. Monograph of the Academy of Natural Science. Philadelphia. 13: 1-213.

[25] Desikachany, T. V. (1959). Cyanophyta. Indian Council of Agricultural Research, New Delhi: 686pp.

[26] Prescott, G. W. (1990). How to know the phytoplanktonic algae, WMC Brown Company publishers. 356pp.

[27] Holm-Harsen, O. (1970). Chlorophyll-a determination improvements in methodology OIKOS, 30: 438-447.

[28] Margalef, D. R. (1957). Diversided de especies en les communideades naturales. -Publ. Inst. Biol.apl. Barcelona. 9: $5-27$.

[29] Jaccard, P. (1912). "The distribution of the flora in the alpine zone". New Phytologist. 11: 37-50.

[30] Nwankwo, D. I. (1998). The influence of sawmill woodwastes on Diatom Population at Okobaba, Lagos- Nigeria. Nigerian Journal of Botany, 11: 15-24.

[31] Olaniyan, C. I. O. (1969). The seasonal variation in the hydrology and total plankton of the Lagos Lagoon of southwestern Nigeria. Nigerian Journal of Science. 3(2): 101-129.

[32] Pudo, J. (1989). Ekologiezne skuki sanieczys-zozenia wod ropa naftowa Peludniowej Nigerii (South Nigeria ecological consequence of crude oil water pollution).-Gosp.Wodna 4: 8587(in polish with English summary).

[33] Nwankwo, D. I. (1996). Phytoplankton diversity and succession in Lagos Lagoon, Nigeria. Avchiv Fur Hydrobiologie. 135(4): 529-542.

[34] Barclay, M. H. (1966). An ecological study of a temporary pond near Auckland, New Zealand. Australian Journal of Marine and Freshwater Reasearch., 17: 239-258.

[35] Onynekan, J. A. (1987). Benthic macrofauna communities of Lagos Lagoon Nigeria. Nigerian Journal of Science. 21(182): 45-51.

[36] Nwankwo, D. I. and Onitiri, A. O. (1992). Periphyton community on submerged aquatic macrophytes (Hornwort and Bladderwort) in Epe Lagoon, Nigeria. Agric. Sci. Technol. 2 (2):135-141.

[37] Patrick, R. (1965). The effect of varying amount and ratios of nitrogen and Phosphate on algal bloom. Proceedings of the $21^{\text {st }}$ Annual Industrial Waste Conference, Purdue University, Indiana, 208pp.

[38] Webb, J. E. (1960). Biology in the tropics. Nature, London 188 (4751): 617-619.

[39] Karentz, D. and McIntire, C. D. (1977). Distribution of diatoms in the plankton of Yaquing Estuary Oregon. J. Phycol. 13: 379-388.

[40] Walsby, A. E. and Reynolds, C. S. (1979). "Sinking and floating in phytoplankton Ecology". In: I. Morris, (ed.). The Ecology of Phytoplankton. Blackwell Scientific Publication Limited, London. 684pp. 